\title{
TECHNOLOGICAL CHANGES IN THE WORK OF ACCOUNTANTS AND CHANGES OF EDUCATION OF ACCOUNTING STUDENTS
}

\author{
Cyryl Kotyla \\ Department of Accounting, Faculty of Management, University of Gdansk (Poland)
}

\begin{abstract}
The first two decades of the 21 st century is a period of large changes in IT technology, which translates into a change of accounting professionals work. Instead of a calculator, paper T-accounts, there were changes resulting from the development of IT technology like:

- electronic documents that replaces traditional paper documents,

- electronic signature that replaces the traditional handwritten signature,

- shipment of electronic documents to tax authorities in the form of xml files replacing the transfer of paper copies of accounting documents.

The above changes necessitate a change of education of accounting students, because in addition to teaching the accounting principles and standards themselves, the job technique itself and the modern work environment play an increasingly important role in the accounting professionals work.

The study analyzed the current methods and curriculum of education of accounting students of the Faculty of Management at the University of Gdansk in the context of their relevance to today's accounting work environment. As a result, areas requiring updating were established.

The theoretical considerations were supported by a survey conducted among students of the summer semester 2019/2020 of the specialization in Accounting. The aim of the study was to gather students' opinions on the validity of teaching methods and subject them to evaluation of proposals for future changes in teaching methods.

The study also contains a proposal for necessary changes to adapt the curriculum of accounting students of the Faculty of Management at the University of Gdansk.
\end{abstract}

Keywords: Electronic signature, computer accountants books, electronic shipment to the tax office, SAF-T files (Standard Audit File-Tax).

\section{Introduction}

Until quite recently the accountant in Poland was associated with a stack of documents, paper-based account books, a calculator and a pencil in his hand. This image has long since gone to the past, and today's accounting work environment looks completely different than it looked a few years ago. The last two decades of the twentieth century is a period of rapid revolution in the development of accounting tools, which is associated with the dynamic development of computers and computer software. The first, very significant stage of this revolution was the introduction to the accounting of computerized registration systems, which replaced the previously used accounting books in paper form. In the initial stage it was very difficult, because the accountants are a very conservative profession, and hence reluctant to change. With time, however, accountants changed their attitude to computer accounting, because there were noteworthy benefits and simplifications in the daily work associated with keeping accounting books in electronic form. As a result, nowadays it is difficult to imagine that any company would keep accounting books differently than using the finance and accounting system.

The beginning of the 21 st century is another revolutionary change in the everyday tools used in accounting, changes related to the digitization of our business and private life, and, among others, introduction of:

a) a mandatory electronic system for settling social security contributions (the Payer system),

b) electronic invoices (e-invoices in $\mathrm{xml}$ format) replacing invoices in traditional paper form,

c) the obligation to prepare and submit tax returns to tax authorities only in electronic form,

d) the obligation to prepare financial statements within the meaning of accounting only in electronic form (so called e-financial reports), 
e) an electronic signature that replaces the traditional signing of documents, including the introduction of the obligation to electronically sign e-financial reports and tax declarations,

f) electronic document flow systems (DMS i.e. document Management System) inside many organizations.

Today's accounting is therefore innovative and based on the latest achievements of computer technology. The aim of the study is to assess whether the above changes were reflected in the teaching programs of the accounting students of the Faculty of Management at the University of Gdansk, who will have to use the latest technology in their daily work.

The theoretical considerations were supported by a survey conducted among students of the summer semester 2019/2020 of the specialization in Accounting. The aim of the study was to gather students' opinions on the validity of teaching methods and subject them to evaluation of proposals for future changes in teaching methods. The study, due to the limited size of the examined group, is not exhaustive, and is treated only as an indication of the direction of future changes in the methods of education of accounting students.

\section{Electronic reporting in the practice of Polish enterprises}

As mentioned earlier, the most important changes in accounting in Poland in the 21 st century are changes that involve the introduction of electronic reporting. This is followed by the popularisation of the electronic signature, which is necessary for signing electronic reports, because the electronic document requires an electronic signature.

The first large area of changes was the introduction of a universal obligation to settle electronically with tax authorities in the field of VAT. Every VAT payer is currently obliged to prepare and send to the tax authorities electronic VAT declarations (Act of 29 August of 1997) and corresponding SAF-T files (Standard Audit File-Tax) (Act of 11 March 2004). The introduction of this obligation freed the tax authorities from tedious and time-consuming tax inspection procedures, because now all VAT settlement data are sent by taxpayers and are located on the servers of the Ministry of Finance. As far as tax reports are concerned, it has already been introduced an obligation to provide some reports on PIT and CIT by electronic means, which however did not have such a universal dimension as the introduced obligation to submit VAT returns and SAF-T files.

The second area that has been covered by digitalization is the area of annual financial statements in the sense of accounting (balance sheet, profit and loss account, cash flow, etc.). The year 2018 is the first financial year for which entities conducting business activity had to transfer their balance sheets and profit and loss accounts electronically (Act of 29 September 1994). The end of the first quarter of 2019, the period when these reports were to be created, electronically signed and electronically transferred to the registration authorities, it was a very hot period, because most of the entities for a long time ignored this obligation.

And the third area of major changes is the area associated with the electronic signature, as the preparation and transmission of reports in electronic form requires the submission of an electronic signature. The area of the electronic signature itself is a very foggy and unclear area. On the one hand, in Poland, as well as in other EU countries, the eIDAS Regulation (Regulation (EU) No 910/2014) is in force, whose purpose was to sort out problems related to the electronic signature. On the other hand, there is quite a lot of legal regulations in Polish legislation that have not yet been adjusted to the eIDAS regulation both in terms of legal norms and - what is also important - terminology being used. All this means that electronic signing is neither as popular as one would expect nor as simple as it was supposed to be.

\section{Current curricula of accounting of the Faculty of Management at the University of Gdansk}

The changes in the accounting technique described above - changes related to electronic reporting and electronic signing - can be compared to changes taking place at the end of the 20th century, which were related to the transition from paper accounting (manual records in paper books) to computer accounting (records in computer financial and accounting system). Both these past changes required, as well as current changes, require appropriate adjustment of students' curriculum, as the accounting technique is as important for the future accountant as well as the knowledge of accounting standards and tax rules.

A review of current curricula (2019/2020) at the undergraduate and graduate studies at the University of Gdansk shows that while issues related to computerized accounting have already been included in the student curriculum - there is a subject of Computerized Accounting on the 5th semester of 
bachelor degree - issues related to electronic tax and financial reporting have not yet been reflected in curricula (Study programs of the Faculty of Management at the University of Gdansk).

In order to empirically verify the need for changes in the curriculum of accounting students of the Faculty of Management at the University of Gdansk, a survey was conducted. This study aimed to determine whether current accounting students have heard about changes related to the digitization of financial and tax statements and whether they deem it necessary to have their curriculum adjusted accordingly so that these issues become a subject of teaching and practical exercises. The study was conducted during the summer semester 2019/2020 among a group of full-time and extramural students of accounting specialization. As a result of the study, it was found that students participating in the survey:

1. are not able to distinguish particular types of electronic signature and the rules for their use in order to sign accounting and tax documents, and

2. agreed that the study program requires correction of issues related to the creation, signing and sending of electronic reports.

\section{Conclusions}

In connection with the current technological changes in accounting profession, it should be introduced into the curriculum of accounting students of the Faculty of Management at the University of Gdansk:

1. theoretical classes, during which students would get acquainted with the legal issues of electronic signature, so that they would be able to distinguish the basic types of electronic signature and the possibility of their application in accounting practice,

2. practical classes, during which students could prepare electronic tax declarations, electronic financial statements and sign them with an electronic signature and send them electronically to the test server of the Ministry of Finance, which has just been made available by the Ministry of Finance for such purposes.

Looking at the above, it seems that the changes necessary to introduce in the teaching programs of the accounting students of the Management Faculty of the University of Gdansk are relatively simple.

Summarizing, students' education programs should be updated both in situations of substantive changes in accounting and tax rules, which seems to be obvious, as well as should be updated also when introducing major changes in the very work of accounting. Otherwise, graduate graduates, despite the substantive preparation, will not be a full-fledged employee for future employers.

\section{References}

Act of 29 August of 1997, The Tax Ordinance Act, art. $82 \S 1 \mathrm{~b}$

Act of 11 March 2004, The Goods and Services Tax Act, art. 99 ust. 11b

Act of 29 September 1994, The Accounting Act, art. 45 ust. 1 f oraz art. 52 ust. 2

Regulation (EU) No 910/2014 of the European Parliament and the Council of 23 July 2014 on electronic identification and trust services for electronic transactions in the internal market and repealing Directive 1999/93/EC

Study programs of the Faculty of Management at the University of Gdansk from its www page, Accessed 24 April, 2019. Retrieved from https://wzr.ug.edu.pl/studia/index.php?str=449\&spec=1\&tr=1\#1 